\title{
Innowacja w kreowaniu wartości konsumenckich jako istotny czynnik podejmowanych wyborów społeczno-ekonomicznych
}

DOI: 10.19195/2083-7763.9.13

\section{Innowacja w kreowaniu wartości konsumentów}

Innowacyjność ściśle wiąże się z współczesnością, jest swoistym katalizatorem zmian zachodzących w świecie, a także motorem dynamicznego rozwoju. Innowacja to między innymi tworzenie i aplikacja nowej wiedzy dotyczącej takich pojęć, jak kultura, technologia, ekonomia, społeczeństwo ${ }^{1}$. Istnieje wiele definicji zjawiska innowacji. Według P.F. Druckera innowacja „jest specyficznym narzędziem przedsiębiorczości”2. Z kolei Z. Pietrusiński, definiując innowację, określił ją jako celowe zmiany wprowadzane przez człowieka, a Ph. Kotler stwierdził, że odnosi się ona do jakiegokolwiek dobra, usługi lub pomysłu, który jest postrzegany przez kogoś (na przykład producenta czy konsumenta) jako nowy ${ }^{3}$.

W opisie innowacji można wyróżnić dwa podstawowe podejścia:

- wynikowe - innowacja to zmiana, która skutkuje wprowadzeniem nowego czy udoskonalonego produktu, procesu, rozwiązania o charakterze organizacyjnym;

- procesowe - innowacja to sekwencja działań zmierzających do zastosowania nowych czy udoskonalonych rozwiązań, czyli wiąże się z procesem zarządzania ${ }^{4}$.

1 A. Morawiak, Skuteczne zarzadzanie procesami komunikacji jako element innowacyjnego zarządzania organizacją, [w:] Innowacje w biznesie, red. A. Styś, A. Dejnaka, Warszawa 2018, s. 195.

2 P.F. Drucker, Innowacja i przedsiębiorczość. Praktyka i zasady, przeł. A. Ehrlich, Warszawa 1992, s. 39.

${ }^{3} \mathrm{Ph}$. Kotler, Marketing. Analiza, planowanie, wdrażanie i kontrola, przeł. J. Środa, M. Zawiślak, Warszawa 1994, s. 322.

${ }^{4}$ G. Osbert-Pociecha, Innowacje - zagadnienia ogólne i definicyjne, [w:] Innowacje w biznesie..., s. 20. 
Innowacyjność zatem jest dziś wymogiem, podstawą istnienia społeczeństwa oraz każdej organizacji. Przedsiębiorstwa, które nastawione są na odnoszenie sukcesów, muszą stale poszukiwać nowych dróg rozwoju, a innowacje są siłą napędową organizacji. Stanowią one podstawowy czynnik i stymulator rozwoju przedsiębiorstwa ${ }^{5}$.

Innowacja jest zmianą implementowaną przez człowieka i polega na zastąpieniu istniejącego stanu rzeczy nowym ${ }^{6}$. Jest to każda zmiana, która powinna ulepszać istniejący stan rzeczy, produkt, usługę. Jest ona motorem rozwoju i osiągania pożądanego stanu. Każda innowacja powinna kreować wartości pozwalające nie tylko na rozwój społeczny, gospodarczy, ekonomiczny, lecz także indywidualny konsumentów. Centralne miejsce w systemie wartości społecznych zajmują wartości konsumpcyjne i tutaj należy upatrywać innowacyjnego podejścia do produkcji, usług, produktów i wyborów konsumentów. Branie pod uwagę innowacji produktowych, procesowych czy organizacyjnych jest podstawą rozwoju organizacji, a także pozyskiwania akceptacji i przychylności różnych interesariuszy, w tym również konsumentów. Dzięki innowacji wykorzystywanej w organizacjach wdrażane są nowe produkty, rośnie ich absorpcja oraz świadomość odbiorców tych produktów i usług.

Społeczeństwo, w którym żyjemy, jest społeczeństwem wartości, a życie realizuje te wartości. Człowiek jest zobligowany do urzeczywistniania ich w codziennym działaniu ${ }^{7}$. Wartości powstają jako składnik doświadczenia ludzkiego i przeżywane są przez jednostki w różnoraki sposób. Nie istnieją one poza światem społecznym człowieka i są zobiektywizowane w jego produktach pracy, zachowaniach, kulturze i sztuce ${ }^{8}$. Wartość ma złożoną strukturę i choć z zasady nie jest zmienna, to często zmienne są zewnętrzne jej formy w zależności od kontekstu społecznego. Zachowanie konsumenta zgodnie z ogólnie przyjętymi wartościami umożliwia budowanie zaufania między jednostkami, a także między jednostką a producentem określonych dóbr. Zwiększa poczucie bezpieczeństwa i przynależności do danej grupy, skutecznie rozwija zaangażowanie w obronę istniejących dóbr.

Człowiek odczuwa konieczność poznania i posiadania wartości tudzież ich realizowania. [...] Natura ludzka polega na nieustannym wysiłku przekraczania granic zwierzęcości tkwiącej w człowieku i wyrastania ponad nią człowieczeństwem i rolą człowieka jako twórcy wartości.

${ }^{5} \mathrm{~S}$. Khaijeh, Innovation value chain as predictors for innovation staretgy in Malaysian telecommunication industry, „Problems and Perspectives in Management” 12, 2014, nr 4, s. 531-537.

${ }^{6}$ A. Wallis, W. Denga, Innowacyjność $w$ sektorze małych i średnich przedsiębiorstw $w$ Polsce, „Koszalińskie Studia i Materiały” 2004, nr 7, s. 35-51.

7 M. Wawrzak-Chodaczek, Wartości w komunikowaniu, Toruń 2009, s. 23.

8 A. Perchla-Włosik, System wartości i współczesne trendy oraz zachowania konsumpcyjne społeczności wielkomiejskiej na przykładzie mieszkańców Wrocławia, Wrocław 2012, s. 6. 
Bez tej misji i tego wysiłku wyrastania ponad samego siebie człowiek zapada z powrotem i bez ratunku w swoją czystą zwierzęcość, która stanowi jego śmierć 9 .

Są to słowa znanego polskiego filozofa R. Ingardena. Problematyką wartości interesowali się między innymi socjolodzy z tak zwanego nurtu socjologii rozumiejącej. W metodologicznej części pierwszej pracy W.J. Thomasa i F. Znanieckiego znajduje się pierwsze systematyczne omówienie pojęcia wartości ${ }^{10}$. W późniejszym czasie było ono przedmiotem zainteresowania specjalistów różnych dziedzin nauki, a także ekonomistów, polityków czy działaczy kultury. Powstało wiele definicji usiłujących określić, czym jest wartość. Jedną z nich jest definicja skonstruowana przez J. Szczepańskiego:

Jest to dowolny przedmiot materialny lub idealny, idea lub instytucja, przedmiot rzeczywisty lub wyimaginowany, w stosunku do którego jednostki lub zbiorowości przyjmują postawę szacunku, przypisując mu ważną rolę w swoim życiu i dążenie do jego osiągnięcia odczuwają jako przymus. Wartościami są te przedmioty lub stany rzeczy, które jednostkom i grupom zapewniają równowagę psychiczną, dają zadowolenie, dążenie do nich lub ich osiągnięcie daje poczucie dobrze spełnionego obowiązku lub te, które są niezbędne dla utrzymania wewnętrznej spójności grupy, jej siły i jej znaczenia wśród innych grup ${ }^{11}$.

Według Słownika języka polskiego wartość to „to, ile coś jest warte, cecha przedmiotu, materiału, znaczenia, ważność"12. Jest to pewien „system norm regulujących ludzkie zachowania, których realizacja daje poczucie satysfakcji i przekonanie o możliwości osiągnięcia życiowego sukcesu”"13.

W psychologii wartości traktowane są zwykle jako zjawiska psychiczne o charakterze poznawczym i zbliżone są do terminu „postawa”. Są to działania celowe jednostki i jej zdolność do rozwoju indywidualnego oraz społecznego, coś godnego pożądania ${ }^{14}$. Wprowadzenie człowieka w świat wartości poznawczych, etycznych i estetycznych to przede wszystkim kształtowanie w nim określonych potrzeb i upodobań, pobudzanie dociekliwości w poszukiwaniu prawdy, umiejętności rozróżniania rzeczy dobrych od złych, rozwijanie wrażliwości i dyspozycji twórczych ${ }^{15}$. Tematem niniejszego artykułu nie są wartości same w sobie, ale wartości, którymi kieruje się konsument w swoich wyborach, a także wytwórca produktu istniejącego na rynku, w tym głównie produktu innowacyjnego.

9 R. Ingarden, Książeczka o człowieku, Kraków 1987, s. 19.

10 T.J. Thomas, F. Znaniecki, The Polish Peasant in Europe and America, cz. 1, Boston 19181920, s. 21.

11 J. Szczepański, Elementarne pojęcia socjologii, Warszawa 1970, s. 97-98.

12 Wartość, [hasło w:] Słownik języka polskiego PWN, red. W. Doroszewski, Warszawa 1968, s. 879 .

13 W. Smid, Marketing - pod presja globalizacji, Warszawa 2002, s. 106.

14 J. Gajda, Wartości w życiu człowieka, Lublin 1997, s. 12.

15 Ibidem, s. 13. 


\section{Konsumpcja a wyznawane przez konsumentów wartości}

Przez wiele lat $\mathrm{w}$ społeczeństwie istniało przekonanie, że ekonomia to dziedzinanaukipozbawionajakichkolwiek wartościpoza materialnymi.Przedsiębiorcy, kierując się osiągnięciami ekonomii, byli nastawieni na zysk. Między innymi dzięki takiej postawie powstało pojęcie konsumpcji, zwanej potocznie spożyciem, czyli działaniami ludzi mającymi na celu zaspokajanie ich osobistych potrzeb. Konsumowanie różnego rodzaju towarów istniało od zarania dziejów ludzkich. Już w pismach Arystotelesa, Platona czy nawet św. Tomasza z Akwinu można znaleźć wzmianki na temat zakupów, sprzedaży czy cen ${ }^{16}$. Przełom XVIII i XIX wieku pogłębia zainteresowanie zjawiskiem konsumpcji. Pod koniec XIX wieku zauważono, że ludzie dążą do maksymalizacji korzyści, osiągania przyjemności i zaspokajania własnych potrzeb. Człowiek często wydatkował bezcelowo i zbytkowo, celebracja zakupów pozwalała oderwać się od codziennego życia i zaznać elegancji i luksusu. Konsument chciał mieć więcej i więcej często zbędnych produktów. Zaspokajanie podstawowych potrzeb jednostki zastąpiono dążeniem do satysfakcji za pomocą konsumpcji. Posiadanie dóbr i ukierunkowanie życia na gromadzenie ich stało się celem samym w sobie. Konsumpcjonizm często wytwarza w społeczeństwie atmosferę współzawodnictwa i dążenia do celu za wszelką cenę, powoduje rozpad więzi, nie tylko lokalnych, lecz także rodzinnych, prowadzi niejednokrotnie do różnego rodzaju patologii. Z. Bauman uważał, że konsumpcja wyznacza nowe style życia oraz rekonstruuje strukturę społeczną. „W drugiej wersji nowoczesności, nowoczesności konsumentów, brutalnym niekwestionowanym faktem jest to, że trzeba być konsumentem, zanim można pomyśleć o staniu się czymkolwiek w szczególności"17. Człowiek otoczony przedmiotami kształtuje własną, indywidualną konsumpcję; można powiedzieć, że konsumpcja pochłania nasze życie ${ }^{18}$.

Należy również podkreślić, że konsumpcja wyznacza pozycję społeczną, a także wartości, którymi kieruje się konsument. Coraz częściej przeważa stwierdzenie, że człowiek, który nie posiada w wymiarze gospodarczym, nie istnieje ${ }^{19}$. Konsument kupuje już nie tylko to, co mu potrzebne, lecz także to, czego może nigdy nie wykorzysta. Konsumpcja wkroczyła w przestrzeń i czas dzięki osiągnięciom nowoczesnej nauki. „Tradycyjne i nowe środki konsumpcji dobijają się do naszych drzwi tak mocno i często, że wielu z nas po prostu się poddało i wpuściło wszystkie" 20 . Ponadto dzięki nowoczesnym formom transportu, wynalazkom audiotele i sprzedaży internetowej czasowe bariery konsumowania doprowadziły

16 J.K. Galbraith, Ekonomia w perspektywie. Krytyka historyczna, Warszawa 1992, s. 36-37, 42.

17 Z. Bauman, Praca, konsumpcjonizm i nowi ubodzy, Kraków 2006, s. 59.

18 G. Ritzer, Magiczny świat konsumpcji, przeł. L. Stawowy Warszawa 2004, s. 9.

19 A. Perchla-Włosik, System wartości i współczesne trendy oraz zachowania konsumpcyjne społeczności wielkomiejskich na przykładzie mieszkańców Wrocławia, Wrocław 2012, s. 96.

20 G. Ritzer, op. cit., s. 248. 
do implozji czasu konsumpcji. Wszystkie zachodzące zjawiska mają wpływ na konsumentów oraz ich pobudki w podejmowaniu decyzji zakupowych. Najpierw pojawia się potrzeba oparta na systemie wartości konsumenta, następnie zgodnie $\mathrm{z}$ hierarchią potrzeb dokonuje on zakupu odpowiedniego produktu. Warto zadać pytanie, jak funkcjonuje konsument.

Według J. Baudrillarda dla konsumenta ważne są nie tylko dobra, lecz także potrzeby. Zauważył jednak, że nie chodzi tu o potrzebę posiadania produktu, ale przede wszystkim o potrzebę społecznego znaczenia i zajmowania określonych pozycji.

Sekwencja potrzeb na wzór sekwencji dóbr ma charakter społecznie wybiórczy, potrzeby i ich sposoby zaspokojenia przenikają ku dołowi na mocy bezwarunkowo obowiązującej zasady swego rodzaju społecznego imperatywu kategorycznego, którą jest utrzymanie dystansu i różnic za pomocą znaków ${ }^{21}$.

Obecnie priorytety ekonomiczne związane z posiadaniem i dążeniem do dobrobytu ulegają zmianie. Coraz częściej w hierarchii potrzeb wyższe miejsce zajmują aspiracje niematerialne. R. Inglehart pisał, że „wartości zachodnich społeczeństw ulegają przemianom w kierunku od zdecydowanego nacisku na kwestie materialne i bezpieczeństwo fizyczne do coraz większej istotności jakości życia"22. Znaczenia nabiera samorealizacja i rozwój indywidualny. Środki materialne i posiadane dobra nadal są bardzo ważne w życiu codziennym człowieka, ale ważna jest też partycypacja $\mathrm{w}$ podnoszeniu jakości produktów, jak również świadomość ekologiczna. Obecnie konsument coraz częściej ma możliwość wywierania wpływu na rodzaj i jakość oferty producenta. Dzięki nowym środkom przekazu ma większe możliwości nabycia dobrego produktu, a unikania złego. Producenci zauważyli, że kierując się wyższymi wartościami i postępując etycznie w biznesie oraz uwzględniając działania proekologiczne, mogą rozwijać firmę, powiększać zyski, a także budować reputację firmy wśród pracowników i społeczeństwa ${ }^{23}$. Zysk jest jednym z elementów składowych firmy. Przedsiębiorcy muszą brać pod uwagę nie tylko wyzwania rynku, lecz także wymagania świadomych konsumentów, ich potrzeby, wartości panujące w społeczeństwie i - co ważne muszą uwzględniać problemy współczesnego świata ${ }^{24}$. Kierowanie się zasadami etycznymi, a także odwoływanie się do wartości jest sposobem na wyróżnienie się danej firmy na rynku. „Konsument, wybierając dany produkt, nie tylko dostaje ukrytą pod opakowaniem jego fizyczną formę i właściwości, ale także wartość dodaną, nową jakość, możliwość identyfikacji, realizacji swoich wewnętrznych potrzeb, nie tylko materialnych"25.

21 J. Baudrillard, Społeczeństwo konsumpcyjne. Jego mity i struktura, przeł. S. Królak, Warszawa 2006, s. 66.

${ }^{22}$ R. Inglehart, The Silent Revolution: Changing Values and Political Styles Among Western Publics, Princeton 1977, s. 3.

23 J. Bakalarska, Marketing wartości, Lublin 2016, s. 21.

24 Ibidem.

25 Ibidem, s. 22. 
Nie tylko konsumenci, lecz także firmy coraz częściej w codziennej działalności komunikują swoje wartości oraz realizują wyższe cele, co umożliwia im budowanie relacji z pracownikami i społeczeństwem. Taka postawa pozwala konsumentom na dematerializacje dóbr - dobra stają się nośnikami usług i źródłem prestiżu społecznego. Na zmianę zachowań konsumenckich zwróciła uwagę B. Frątczak-Rudnicka, wskazując cztery tendencje występujące w społeczeństwach europejskich:

1. Reduce - ograniczenie odpadów przez ograniczenie i świadomą konsumpcję, dokonywanie zakupów w sklepach dyskontowych. Produkty w tych sklepach cieszą się wysoką jakością, a przede wszystkim pochodzą z lokalnych źródeł. Cechują je autentyczność i ekologia.

2. Reuse - ponowne użycie. Polega na kupowaniu rzeczy używanych bądź na pożyczaniu, wymianie między konsumentami dóbr i usług. Dzięki stronom internetowym, takim jak tablica.pl, wzrasta liczba chętnych do wymiany, pożyczania czy dzielenia się.

3. Recycle - odzyskiwanie wtórne, wtórne przetwarzanie. Zorientowane jest na ekologię, produkty jednorazowego użytku wypierane są przez te wielorazowe. Tutaj stawia się na ekologię i zrównoważoną konsumpcję. Jest to konsumpcja świadoma i odpowiedzialna. Konsumenci korzystają z dóbr w sposób mądry, zrównoważony i zgodny z potrzebami. Zrównoważone podejście do konsumpcji pozwala na poszanowanie dóbr odnawialnych i nieodnawialnych. Konsument XXI wieku patrzy przez pryzmat przyszłości. Odrzuca niezdrowy styl życia, spowalnia tempo, a jego wybory, zgodne z preferowanymi wartościami, mają podnosić jakość życia. Konsumpcja zrównoważona dotyczy: ekonomii, ekologii, aspektu społecznego, psychologicznego, demograficznego ${ }^{26}$.

4. Redesing - przeprojektowanie, przekonstruowanie, poszukiwanie tańszych alternatyw danego produktu, a także przeprojektowanie produkcji przez producentów w celu zmniejszenia degradacji środowiska. Redesing to „ogół działań o charakterze kreatywnym dotyczącym projektowania dóbr i usług, których celem jest tworzenie wartości dodanej z perspektywy klienta, firmy oraz w wymiarze całego kraju jego powstania" ${ }^{27}$. Ważna jest tu funkcjonalność produktu i jego ergonomia. Konsument coraz częściej, poza ceną, zwraca uwagę na produkt, jego cykl produkcyjny, związek ze środowiskiem, a także sposób jego komunikowania. Produkt musi uzyskać nową, lepszą formę, firma musi iść z duchem czasu, czyli na przykład chronić środowisko i jego zasoby ${ }^{28}$.

${ }^{26}$ D. Kiełczewski, Przedsiębiorstwo a ksztaltowanie proekologicznych wzorów konsumpcji, [w:] Zrównoważony rozwój w przedsiębiorstwie, red. A.Wasiak, G. Dobrzański, Białystok 2005, s. 32.

27 Ł. Mamica, Wzornictwo przemysłowe jako determinanta konkurencyjności gospodarki, Kraków 2012, s. 5.

28 B. Frątczak-Rudnicka, Regeneracja. Odwrót od hiperkonsumpcji, reprint, „Think-Tank” 2010/2011, s. 1-9. 
Promując tę postawę, A. Cortina, filozof pozostająca pod wpływem etyki Kanta, zbudowała trzy normy etyczne związane z konsumpcją:

- konsumuj tak, aby twoje normy nie były długotrwałe, niebezpieczne dla środowiska naturalnego;

- konsumuj tak, abyś jednocześnie wspierał dążenie do wolności każdego człowieka, a także twojej osoby, jak też każdej innej osoby;

— przyjmuj normy takiego stylu konsumpcji, który by wspierał twoje dążenia do wolności [...] i umożliwiał zdobywanie bogactwa jako celu życiowego ${ }^{29}$.

Wartości preferowane przez konsumentów, zawierające pierwiastek etyczny, sprawiają, że konsumenci przy wyborze dóbr konsumpcji biorą pod uwagę moralną stronę tych dóbr. Dzięki takiej postawie w ostatnich latach rozwija się ruch slow food w konsumpcji, czyli świadome i mądre podejście do konsumpcji. Wartości dotyczące biznesu są ściśle związane z wartościami klienta, z jego systemem przekonań, a także misją samej organizacji. Zysk jest pośrednim elementem sukcesu, istotną jego częścią składową są wymagania coraz bardziej świadomych konsumentów. Chociaż ekonomia jest ważna, to dzięki preferowanym wartościom, etyce i akceptacji zachodzących zmian rozwija się świadomość społeczna i ekologiczna, przyjazne środowisku naturalnemu - przemyślane, powolne zakupy, wybór najlepszych produktów, ich selekcja czyli powolna, przemyślana konsumpcja. W celu ograniczenia konsumpcji świadomy konsument na podstawie preferowanych wartości zwraca się w stronę dekonsumpcji, czyli

- ograniczenia konsumpcji ze względu na wzrost niepewności sytuacji gospodarczej;

- ograniczenia konsumpcji na rzecz jej jakości;

— zwiększenia konsumpcji w sferze niematerialnej;

- ograniczenia konsumpcji ze względów racjonalnych ${ }^{30}$.

Współczesny konsument, zmęczony masową konsumpcją i jej wpływem na degradację nie tylko środowiska, lecz także istniejących normi wartości, ogranicza konsumpcję w sferze materialnej na rzecz niematerialnej, czyli zastępuje wiele produktów usługami. Wartość emocjonalna przewyższa wartość dóbr użytkowych ${ }^{31}$.

Cechą konsumpcjonizmu jest wywołanie permanentnego pragnienia nabywania i konsumowania towarów oraz usług, natomiast ze strony producentów czy handlowców jest to oczywista chęć pomnożenia zysków ${ }^{32}$. Konsumpcji nie da się odrzucić, ale można zmienić jej kierunek. Konsument XXI wieku nastawiony

29 F. Bylok, Konsumpcja, konsument $i$ społeczeństwo konsumpcyjne we wspótczesnym świecie, Katowice 2013, s. 219.

30 J. Woś, Zachowania konsumenckie - teoria i praktyka, Poznań 2009, s. 99.

31 W. Patrzałek, Dekonsumpcja - racjonalny wybór czy ekonomiczny przymus?, „Forum Socjologiczne" 4, 2013, s. 19.

32 A. Dąbrowska, M. Janoś-Kresło, Od konsumpcjonizmu do niedoborów, „Forum Socjologiczne” 4, 2013, s. 92. 
jest na etyczną konsumpcję. Warto się zatem zastanowić, jakie podejście charakteryzuje współczesne organizacje wytwarzające innowacyjne dobra i usługi.

\section{Zrównoważona konsumpcja a społeczna odpowiedzialność biznesu w obliczu zmian}

W organizacjach biznesowych coraz częściej zwraca się uwagę na zrównoważoną konsumpcję oraz społeczną odpowiedzialność biznesu. Zrównoważona konsumpcja pokazuje, jak konsument, w racjonalny sposób zaspokajając swoje potrzeby podnoszące jakość życia, minimalizuje zużycie zasobów naturalnych, niezbędnych następnym pokoleniom. Istotą tej koncepcji jest zachowanie właściwych proporcji między kapitałem ekonomicznym, ludzkim i przyrodniczym ${ }^{33}$. Według D. Kiełczewskiego trwała i zrównoważona konsumpcja jest zrównoważona w kilku aspektach:

- ekonomicznym - ustalenie takich proporcji między bieżącą a przyszłą konsumpcją, które nie przyczyniają się do zaburzeń równowagi gospodarczej;

- ekologicznym - konsumpcja przy zachowaniu użyteczności i jakości zasobów naturalnych i przyrodniczych;

- społecznym - preferowanie konsumpcji niepowodującej problemów społecznych i względnie równa jej dostępność niezależnie od czasu i przestrzeni;

- psychologicznym - konsumpcja powoduje wzrost jakości życia;

- demograficznym - uwarunkowania demograficzne nie powodują bariery wzrostu konsumpcji;

- przestrzennym - nie jest naruszany ład przestrzenny;

— intertemporalnym — powyższe założenia są do zrealizowania w ograniczonej perspektywie czasowej ${ }^{34}$.

Zrównoważona konsumpcja jest odpowiedzią na problemy ekologiczne i globalne, a także pokazuje konsumencką mobilizację i siłę sprawczą samych konsumentów wobec nieuczciwych producentów ${ }^{35}$. Konsumpcja etyczna uwrażliwia na potrzeby społeczne i podyktowana jest przemianą wartości i postaw. Konsument odpowiedzialny widzi przez pryzmat przyszłości, zna swoje prawa i potrafi je egzekwować. Następuje przełom w konsumpcji etycznej, świadomej i zsynchronizowanej z potrzebami przyszłych pokoleń.

Organizacja tworzona jest przez ludzi, ale również dla ludzi. Postępowanie członków danej organizacji ma wpływ na całościowe postrzeganie firmy. Aby działalność całego przedsiębiorstwa była etyczna, działanie osób w nim zatrudnionych musi być właściwe. Już Arystoteles uważał, że cała wiedza i poznanie

${ }^{33}$ M. Janoś-Kresło, B. Mróz, Konsument i konsumpcja we współczesnej gospodarce, Warszawa 2006, s. 75.

34 D. Kiełczewski, op. cit., s. 57.

35 A. Neale, Prace geograficzne, Kraków 2015, s. 142. 
ludzkie muszą służyć drugiemu człowiekowi. Etyka jest nieodłączną cechą jednostki ludzkiej i warunkiem jego psychologicznej jedności $z$ otoczeniem. Jedna definicja podkreśla, że etyka może być definiowana w kontekście jednostkowym, podkreślającym, że ludzie mają etykę, zachowania etyczne są różne u poszczególnych osób i etyka jest pojęciem względnym ${ }^{36}$. Etyka powinna przyczyniać się do równowagi pomiędzy zyskami ekonomicznymi a dbaniem o realne potrzeby otoczenia. Dzięki etyce organizacje uświadamiają sobie swoją odpowiedzialność, wpływ podejmowanych decyzji na środowisko i grupy społeczne. Etyka jest zbiorem specjalistycznych norm sprzyjających umacnianiu właściwych relacji z otoczeniem, a także umożliwia pozyskiwanie nowych klientów, co prowadzi do wzrostu ekonomicznego. Pomiędzy ekonomią a etyką istnieje pewna zależność, gdyż skutki działalności firmy mierzone są korzyściami i szkodami, nie tylko dla firmy, lecz także jej ogólnie pojętego otoczenia.

A. Smith dostrzegał konieczność zachowywania umiaru w poszukiwaniu korzyści, potrzebę troszczenia się o wspólne dobro, uznanie i szacunek dla drugiego człowieka oraz rzetelność w myśleniu i działaniu. Pisał on, że „nie do pomyślenia jest, abyśmy nie pragnęli szczęścia innych ludzi, wszystkich rozumnych niewinnych istot, i nie czuli w jakiejś mierze sprzeciwu wobec ich niedoli” ${ }^{37}$. Firma pragnąca sprawność ekonomiczną pogodzić z wymogami etyki i oczekiwaniami społecznymi musi zdobyć się na kompromis, który będzie instrumentem syntetyzującym te dwa kryteria ${ }^{38}$. Etyka obniża również koszty produkcji dzięki poprawie motywowania pracowników oraz wzroście ich zadowolenia z pracy. Poza tym rozwija takie wartości, jak sumienność, przestrzeganie prawa, uczciwość czy prawdomówność. Już Kant pisał, że „prawdomówność stwierdzeń, których nie można uniknąć, jest formalnym obowiązkiem każdego wobec wszystkich, bez względu na niedogodności narastające dla niego samego lub innych" ${ }^{\prime 3}$. Ponadto wpływa na właściwą atmosferę w pracy, uczciwe wykonywanie obowiązków, utrudnia działania korupcyjne, przeciwdziała dyskryminacji, a także nie przyzwala na zło. Etyka związana jest również z rzetelną i profesjonalną komunikacją. Pozorna komunikacja często osłabia wizerunek firmy zamiast budować. Rozbieżności pomiędzy manifestowaniem zasad a realnym działaniem firmy burzy jej reputację. Niezgodność uwidacznia się najczęściej w zakresie:

- postępowania niezgodnego z zasadami prawa,

- nieprzestrzegania praw człowieka,

- nieposzanowania konkurencji,

- dostarczaniu nieprawidłowych informacji klientowi,

36 R.W. Griffin, Podstawy zarządzania organizacjami, przeł. M. Rusiński, Warszawa 2004, s. 135.

37 A. Smith, Teoria uczuć moralnych, Warszawa 2002, przeł. D. Petsch, s. 35.

38 Z. Malara, Przedsiębiorstwo w globalnej gospodarce. Wyznania współczesności, Warszawa 2006, s. 263.

39 I. Kant, On a Supposed Light to Lie from Altruistic Motives, [w:] idem, Critique of Practical Reason and Other Writings in Moral Philosophy, Chicago 1962, s. 346, tłum. A.M. 
— zachowań charakteryzujących się agresywnym eksploatowaniem środowiska naturalnego,

- unikania odpowiedzialności za produkt i jego jakość ${ }^{40}$.

Każde przedsiębiorstwo powinno mieć kodeks działania oparty na zasadach etyki. Kodeks uściśla, jak przedstawiciele danego zawodu powinni zachowywać się w określonych sytuacjach. Zatem informuje on o wartościach firmy i zaleceniach dotyczących relacji z innymi. Kodeks opiera się na zasadzie wspólnego działania na rzecz wszystkich interesariuszy. Jest on zwykle krótkim i zwięzłym komunikatem, układem moralności praktykowanej przez przedstawicieli konkretnych zawodów.

Czy etyka w biznesie się opłaca? Wbrew obiegowym poglądom, że zysk jest najważniejszy, gospodarka XXI wieku stawia na pracownika i klienta. To ich postępowanie w dużej mierze decyduje, czy firma utrzyma się na rynku. Dostarczanie wartościowych usług i wyrobów przy równoczesnym dbaniu o środowisko naturalne zwiększa konkurencyjność przedsiębiorstwa. Z kolei dbałość o pracowni$\mathrm{ka}$, adekwatne wynagradzanie go za pracę oraz tworzenie nowych miejsc pracy buduje zaufanie do danej firmy. $Z$ drugiej strony, niedotrzymywanie terminów i warunków pracy, zatruwanie środowiska naturalnego, stosowanie kanonów dyskryminacji czy omijanie przepisów prowadzi do upadku firmy. Zaufanie do organizacji obniża koszty transakcyjne i zachęca do kupowania produktów służących dobru społecznemu. Pracownik zmotywowany, pewny uczciwości w miejscu pracy jest wydajny, a koszty jego produkcji są niskie. Ponadto zapobieganie zanieczyszczeniu środowiska jest zyskiem dla całych pokoleń. Jeżeli nie chroni się naszego systemu utrzymującego życie, to wystawia się na niepowodzenie całą kulturę przemysłową ${ }^{41}$. Organizacje pomijające etykę narażają się na utratę rynku, alienację społeczną, a także sankcje prawne. Biznes to ludzie - dobrzy ludzie - odporni na pokusy natychmiastowej przyjemności.

Etyka zwiększa prestiż przedsiębiorstwa oraz integrację pracowników. Umożliwia rozumienie potrzeb przedsiębiorstwa, a także swobodne wyrażanie opinii na temat działalności firmy. Ponadto ułatwia wdrażanie zasad odpowiedzialnego biznesu (CSR - Corporate Social Responsibility). Jest to dobrowolne planowanie działań, umożliwiające pogodzenie interesów społecznych z osiąganiem zamierzonych zysków. Każda organizacja działa w powiązaniu z otoczeniem. Zatem konieczne jest, aby firmy zadbały o środowisko, w którym funkcjonują. Społecz-

40 M. Sagan, I. Sierzputowska, Praktyka skutecznego zarządzania przedsiębiorstwem, Warszawa 2009, s. 144.

${ }^{41}$ C. Francel, Ziemia - mamy problem, [w:] MBA - praktyczna idea najtęższych umysłów biznesu, red. J. Kurtzman, R.W. Griffin, G. Rifkin, Warszawa 2005, s. 60. 
na odpowiedzialność biznesu jest swoistym obowiązkiem dbania o wszystko, co otacza organizację ${ }^{42}$. Jest to działanie, które odciąża rząd w sferze zadań wobec społeczeństwa ${ }^{43}$. Społeczną odpowiedzialność biznesu określa się jako koncepcję, dzięki której przedsiębiorstwa w swojej strategii uwzględniają interesy społeczne i ochronę środowiska. Jest ona traktowana jako długofalowa inwestycja uwzględniająca relacje z interesariuszami, którzy mają faktyczny wpływ na sukces firmy.

Istnieje wiele definicji firmy, które analizują istotę odpowiedzialnego biznesu. Źródeł społecznej odpowiedzialności biznesu można szukać u starożytnych filozofów. Ich idea odpowiedzialności zakładała, że konsekwencją wolności człowieka jest nałożona na niego odpowiedzialność ${ }^{44}$. Uznaje się, że „autentyczna wolność świadoma jest swoich granic" 45 . Za początki nowożytnej odpowiedzialności biznesu uważa się encyklikę Rerum novarum Leona XIII z 1891 roku $^{46}$, gdy zaczął tracić na popularności pogląd, że odpowiedzialność firmy ogranicza się do osiągania zysków. W 1932 roku E. Merrick Dodd stwierdził, że celem przedsiębiorstw jest nie tylko osiąganie zysku, lecz także działanie w interesie społecznym, przyczynianie się do dobra publicznego oraz obowiązek uczestniczenia w życiu otoczenia organizacji ${ }^{47}$. Współczesne definicje podkreślają, że społeczna odpowiedzialność biznesu to „zestaw zobowiązań organizacji do odnowy i umacniania społeczeństwa, w którym funkcjonuje" ${ }^{48}$. Z kolei w definicji zawartej w zielonej księdze Komisji Europejskiej z 18 lipca 2001 roku można przeczytać, że jest to

koncepcja, według której przedsiębiorstwa dobrowolnie uwzględniają aspekty społeczne i ekologiczne w swoich działaniach handlowych oraz w kontaktach ze swoimi interesariuszami. Społeczna odpowiedzialność biznesu to proces, poprzez który przedsiębiorstwa zarządzają relacjami z różnymi stakeholders, którzy mogą mieć realny wpływ na przyzwolenie na ich działalność $[\ldots]$.

CSR powinien zatem być traktowany jako inwestycja, nie koszt, tak samo jak zarządzanie jakością. Firmy mogą podchodzić do CSR w sposób finansowy, handlowy i społeczny, prowadzący do długoterminowej strategii ograniczającej ryzyko związane $\mathrm{z}$ niepewnością. Przedsiębiorstwa powinny realizować swoją odpowiedzialność społeczną zarówno w Europie, jak i na arenie

42 R.W. Griffin, op. cit., s. 17.

43 A. Davis, Public relations, Warszawa 2007, s. 92-93.

44 J. Filek, O wolności i odpowiedzialności podmiotu gospodarującego, Kraków 2002, s. 158-159.

45 K. Jaspers, Wolność i komunikacja, [w:] Filozofia egzystencjonalna, red. L. Kołakowski, K. Pomian, Warszawa 1965, s. 186.

46 Leon XIII, Encyklika o kwestii robotniczej (Rerum novarum), „Znak” 1982, nr 332-334.

47 E. Merrick Dodd, For whom are corporate managers trustees, „Harvard Law Review” 45, 1932, s. 1145.

${ }^{48}$ R.W. Griffin, op. cit., s. 144. 
międzynarodowej, włączając w nią swój cały łańcuch zaopatrzeniowy ${ }^{49}$. Światowa Rada Biznesu ds. zrównoważonego rozwoju definiuje społeczną odpowiedzialność biznesu jako „ciągłe zobowiązanie biznesu do zachowania etycznego oraz przyczyniania się do zrównoważonego rozwoju ekonomicznego poprzez poprawę jakości życia pracowników i ich rodzin, jak również lokalnej społeczności i społeczeństwa jako całości ${ }^{50}$. CSR opiera się na kilku istotnych zasadach:

- odpowiedzialności,

- transparentności,

- etyce,

- poszanowaniu interesariuszy,

- poszanowaniu przepisów prawa,

- poszanowaniu międzynarodowych norm prowadzenia działalności,

- poszanowaniu praw człowieka ${ }^{51}$.

Koncepcja CSR ukazywana jest również jako wzajemne relacje i odpowiednia komunikacja oparta na uczciwości. Sposób, w jaki organizacja komunikuje się ze swoimi klientami, partnerami biznesowymi, pracownikami oraz bliższym i dalszym otoczeniem, decyduje o jej sukcesie na rynku. Należy zwrócić uwagę na obszary społecznej odpowiedzialności przedsiębiorstwa (por. tab. 1).

Zatem dana jednostka organizacyjna powinna wziąć na siebie decyzje i ich konsekwencje. Łatwiej osiągnąć cele, mając społeczne zrozumienie, akceptację i wsparcie ze strony rynku. Czy społeczna odpowiedzialność biznesu przynosi zysk przedsiębiorstwom? Pozytywna opinia publiczna związana ze stosowaniem przez firmy odpowiedzialności [niejasne] przynosi zysk ekonomiczny, a także wpływa na przejrzystość niefinansowych aspektów działania. Umożliwia współuczestnictwo organizacji w rozwiązywaniu problemów społecznych, nakierowana jest na dialog, a także kształtowanie czynników ekologicznych i kulturowych. Przedsiębiorstwa stosujące społeczną odpowiedzialność biznesu udzielają otwartych odpowiedzi na pytanie, $w$ jakich warunkach powstaje produkt czy rodzi się usługa $^{52}$.

49 Green Paper: Promoting a European framework for Corporate Social Responsibility, Commission of the European Communities, Bruksela 18 lipca 2001 r., http://ec.europa.eu/employment_social/ soc-dial/csr/greenpaper_pl.pdf (dostęp: 15.11.2018).

50 www.forbes.pl/artykuły/selekcja/baza-wiedza-csr/definicje-i-standardy-csr,3879,1,12052017 (dostęp: 15.11.2018).

51 M. Popowska, CSR a zarządzanie wiekiem w przedsiębiorstwie, „Przedsiębiorstwo we Współczesnej Gospodarce - Teoria i Praktyka" 2012, nr 3, s. 29.

52 Z. Malara, Przedsiębiorstwo w globalnej gospodarce. Wyzwania współczesności, Warszawa 2006, s. 259. 
Tabela 1. Obszary odpowiedzialności społecznej przedsiębiorstw

\begin{tabular}{|c|c|c|c|}
\hline Ekonomiczny & Ekologiczny & Etyczny & Społeczny \\
\hline $\begin{array}{l}\text { - prowadzenie dzia- } \\
\text { łalności gospodarczej } \\
\text { zgodnie z obowiązu- } \\
\text { jącym prawem } \\
\text { - zapewnienie bez- } \\
\text { pieczeństwa finanso- } \\
\text { wego pracownikom } \\
\text { i właścicielom (ak- } \\
\text { cjonariuszom) } \\
\text { - prowadzenie } \\
\text { uczciwej konkurencji } \\
\text { i reklamy } \\
\text { - uwzględnienie } \\
\text { kryteriów odpowie- } \\
\text { dzialności etycznej } \\
\text { i ekologicznej w pro- } \\
\text { wadzonej działalno- } \\
\text { ści gospodarczej } \\
\text { - troska o stałą } \\
\text { poprawę jakości pro- } \\
\text { duktów } \\
\text { - doskonalenie me- } \\
\text { tod zarządzania } \\
\text { - publikowanie ra- } \\
\text { portów finansowych }\end{array}$ & $\begin{array}{l}\text { - przestrzeganie } \\
\text { obowiązujących } \\
\text { przepisów w zakresie } \\
\text { ochrony środowiska } \\
\text { - minimalizacja } \\
\text { szkód środowisko- } \\
\text { wych we wszelkich } \\
\text { działaniach } \\
\text { - ograniczenie zu- } \\
\text { życia energii i zaso- } \\
\text { bów naturalnych } \\
\text { - zmniejszenie ne- } \\
\text { gatywnego wpływu } \\
\text { produktu na środo- } \\
\text { wisko } \\
\text { - podejmowanie } \\
\text { odpowiedzialności } \\
\text { za wytwarzane pro- } \\
\text { dukty w całym cyklu } \\
\text { życia produktu } \\
\text { - zapewnienie } \\
\text { wszystkim zaintere- } \\
\text { sowanym informacji } \\
\text { na temat wpływu } \\
\text { produkcji i produk- } \\
\text { tów na środowisko } \\
\text { - komunikacja } \\
\text { z otoczeniem } \\
\text { - zapewnienie bez- } \\
\text { pieczeństwa środo- } \\
\text { wiska pracy } \\
\text { - podnoszenie świa- } \\
\text { domości ekologicz- } \\
\text { nej interesariuszy }\end{array}$ & $\begin{array}{l}\text { - dostrzeganie } \\
\text { skutków własnych } \\
\text { decyzji i ponoszenie } \\
\text { za nie odpowiedzial- } \\
\text { ności } \\
\text { - kierowanie się } \\
\text { poszanowaniem } \\
\text { dobra społeczeństwa } \\
\text { w ramach ogólnie } \\
\text { przyjętych norm } \\
\text { - ograniczenie } \\
\text { dążenia do zysku } \\
\text { w sytuacji, gdy może } \\
\text { to prowadzić do } \\
\text { postępowania nie- } \\
\text { zgodnego z ogólnie } \\
\text { przyjętymi normami } \\
\text { społecznymi } \\
\text { - przestrzeganie } \\
\text { istniejącego prawa } \\
\text { - uzupełnianie } \\
\text { prawa tam, gdzie go } \\
\text { nie ma } \\
\text { - rozwijanie prawa } \\
\text { z uwzględnieniem } \\
\text { etycznych zasad } \\
\text { ekonomicznych praw } \\
\text { wolnego rynku }\end{array}$ & $\begin{array}{l}\text { - poszanowanie } \\
\text { lokalnej tradycji, } \\
\text { zwyczajów } \\
\text { - przestrzeganie } \\
\text { prawa lokalnego } \\
\text { - komunikacja spo- } \\
\text { łeczna } \\
\text { - działalność filan- } \\
\text { tropijna }\end{array}$ \\
\hline
\end{tabular}

Źródło: opracowano na podst.: J. Skalik, Zarzadzanie przedsiębiorstwem odpowiedzialnym, [w:] Nowe tendencje w nauce o organizacji i zarzadzaniu u progu XXI wieku, „Prace Naukowe Instytutu Organizacji i Zarządzania Politechniki Wrocławskiej" 2001, nr 71, s. 206; J. Adamczyk, Odpowiedzialność społeczna przedsiębiorstwa w teorii i w praktyce, [w:] Zarządzanie przedsiębiorstwem XXI wieku, red. R. Niestój, Kraków 2002, s. 235; J. RojekNowosielska, Kształtowanie społecznej odpowiedzialności przedsiębiorstwa, Wrocław 2006, s. 49.

Implementacja zasad społecznej odpowiedzialności biznesu pomaga budować wizerunek firmy oraz jej reputację w otoczeniu. Przeciwdziała ewentualnej krytyce, a tym samym zwiększa przewagę konkurencyjną danego przedsiębiorstwa. Uwzględnia prawa pracowników i jednocześnie pomnaża dobrobyt wszystkich zainteresowanych. 
Społeczeństwo jest światem wartości. Codzienna działalność człowieka to urzeczywistnienie określonych wartości związanych z rozwojem bądź degradacją, a nawet regresem społecznym. Pojęcie wartości można definiować jako postawy, normy i zasady postępowania umożliwiające rozwój firmy. Jest to zespół cech właściwych danej organizacji, stanowiących jej atuty. M. Rokeach uważa, że „wartość to trwałe przekonanie, że dany sposób postępowania [...] jest bardziej atrakcyjny niż inne sposoby zachowania"53.

Zatem wartości przedsiębiorstwa to zespół cech stanowiących o jego potencjale, wyróżniających tę konkretną organizację spośród wielu innych. Do wartości przyjmowanych przez organizację należą: „rzetelność, uczciwość, lojalność, poświęcenie, życzliwość w kontaktach międzyludzkich, otwartość na zmianę, jakość, zrównoważony rozwój, odpowiedzialność społeczna, przedsiębiorczośćn"54.

Wartości są podstawą działalności każdej firmy, integrują pracowników, zachęcają do realizacji jej strategicznych celów. Ustrojowe transformacje, a także proces globalizacji przyspieszyły zmiany w różnych dziedzinach zarządzania, również w zarządzaniu kapitałem ludzkim i jego kompetencjami.

\section{Bibliografia}

Adamczyk J., Odpowiedzialność społeczna przedsiębiorstwa $w$ teorii $i w$ praktyce, [w:] Zarządzanie przedsiębiorstwem XXI wieku, red. R. Niestój, Kraków 2002.

Bakalarska J., Marketing wartości, Lublin 2016.

Baudrillard J., Społeczeństwo konsumpcyjne. Jego mity i struktura, Warszawa 2006.

Bauman Z., Praca, konsumpcjonizm i nowi ubodzy, Kraków 2006.

Bylok F., Konsumpcja, konsument i społeczeństwo konsumpcyjne we współczesnym świecie, Katowice 2013.

Davis A., Public relations, Warszawa 2007.

Dąbrowska A., Janoś-Kresło M., Od konsumpcjonizmu do niedoborów, „Forum Socjologiczne” 2013, nr 4.

Drucker P.F., Innowacja i przedsiębiorczość. Praktyka i zasady, przeł. A. Ehrlich, Warszawa 1992.

Duczmala M., Pokusa T., Ekonomiczno-społeczne problemy współczesnego zarządzania i komunikacji, Opole 2008.

Filek J., O wolności i odpowiedzialności podmiotu gospodarującego, Kraków 2002.

Francel C., Ziemia - mamy problem, [w:] MBA — praktyczna idea najtęższych umysłów biznesu, red. J. Kurtzman, R.W. Griffin, G. Rifkin, Warszawa 2005.

Frątczak-Rudnicka B., Regeneracja. Odwrót od hiperkonsumpcji, reprint, „Think-Tank” 2010/2011.

Gajda J., Wartości w życiu człowieka, Lublin 1997.

Galbraith J.K., Ekonomia w perspektywie. Krytyka historyczna, Warszawa 1992.

Green Paper: Promoting a European framework for Corporate Social Responsibility, Commission of the European Communities, Bruksela 18 lipca 2001 r., http://ec.europa.eu/employment_social/ soc-dial/csr/greenpaper_pl.pdf.

53 J. Kościuch, Koncepcja wartości Miltona Rokeacha, „Studia Philosophiae Christianae” 19, 1983, nr 1, s. 83- 96.

54 M. Duczmala, T. Pokusa, Ekonomiczno-społeczne problemy współczesnego zarządzania i komunikacji, Opole 2008, s. 111.

Forum Socjologiczne 9, 2018

(C) for this edition by CNS 
Griffin R.W., Podstawy zarządzania organizacjami, przeł. M. Rusiński, Warszawa 2004.

Ingarden R., Książeczka o człowieku, Kraków 1987.

Inglehart R., The Silent Revolution: Changing Values and Political Styles Among Western Publics, Princeton 1977.

Janoś-Kresło M., Mróz B., Konsument i konsumpcja we wspótczesnej gospodarce, Warszawa 2006.

Jaspers K., Wolność i komunikacja, [w:] Filozofia egzystencjonalna, red. L. Kołakowski, K. Pomian, Warszawa 1965.

Kant I., On a Supposed Light to Lie from Altruistic Motives, [w:] Critique of Practical Reason and Other Writings in Moral Philosophy, Chicago 1962.

Khaijeh S., Innovation value chain as predictors for innovation staretgy in Malaysian telecommunication industry, „Problems and Perspectives in Management” 12, 2014, nr 4.

Kiełczewski D., Przedsiębiorstwo a kształtowanie proekologicznych wzorów konsumpcji, [w:] Zrównoważony rozwój w przedsiębiorstwie, red. A. Wasiak, G. Dobrzański, Białystok 2005.

Kościuch J., Koncepcja wartości Miltona Rokeacha, „Studia Philosophiae Christianae” 19, 1983, nr 1.

Kotler Ph., Marketing. Analiza, planowanie, wdrażanie i kontrola, przeł. J. Środa, M. Zawiślak, Warszawa 1994.

Leon XIII, Encyklika o kwestii robotniczej (Rerum novarum), „Znak” 1982, nr 332-334.

Malara Z., Przedsiębiorstwo w globalnej gospodarce. Wyzwania współczesności, Warszawa 2006.

Mamica Ł., Wzornictwo przemysłowe jako determinanta konkurencyjności gospodarki, Kraków 2012.

Merrick Dodd E., For whom are corporate managers trustees, „Harvard Law Review” 45, 1932.

Morawiak A., Skuteczne zarzadzanie procesami komunikacji jako element innowacyjnego zarządzania organizacja, [w:] Innowacje w biznesie, red. A. Styś, A. Dejnaka, Warszawa 2018.

Neale A., Prace geograficzne, Kraków 2015.

Osbert-Pociecha G., Innowacje - zagadnienia ogólne i definicyjne, [w:] Innowacje $w$ biznesie, red. A. Styś, A. Dejnaka, Warszawa 2018.

Patrzałek W., Dekonsumpcja - racjonalny wybór czy ekonomiczny przymus?, „Forum Socjologiczne" 4, 2013.

Perchla-Włosik A., System wartości i wspótczesne trendy oraz zachowania konsumpcyjne społeczności wielkomiejskiej na przykładzie mieszkańców Wrocławia, Wrocław 2012.

Popowska M., CSR a zarządzanie wiekiem w przedsiębiorstwie, „Przedsiębiorstwo we Współczesnej Gospodarce - Teoria i Praktyka” 2012, nr 3.

Ritzer G., Magiczny świat konsumpcji, przeł. L. Stawowy, Warszawa 2004.

Rojek-Nowosielska J., Kształtowanie społecznej odpowiedzialności przedsiębiorstwa, Wrocław 2006.

Sagan M., Sierzputowska I., Praktyka skutecznego zarządzania przedsiębiorstwem, Warszawa 2009.

Skalik J., Zarządzanie przedsiębiorstwem odpowiedzialnym, [w:] Nowe tendencje w nauce o organizacji i zarządzaniu u progu XXI wieku, „Prace Naukowe Instytutu Organizacji i Zarządzania Politechniki Wrocławskiej" 2001, nr 71.

Słownik języka polskiego PWN, red. W. Doroszewski, Warszawa 1968.

Smid W., Marketing - pod presja globalizacji, Warszawa 2002.

Smith A., Teoria uczuć moralnych, przeł. D. Petsch, Warszawa 2002.

Szczepański J., Elementarne pojęcia socjologii, Warszawa 1970.

Szczepański J., Konsumpcja a rozwój człowieka, Warszawa 1981.

Thomas T.J., Znaniecki F., The Polish Peasant in Europe and America, cz. 1, Boston 1918-1920.

Wallis A., Denga W., Innowacyjność w sektorze małych i średnich przedsiębiorstw w Polsce, „Koszalińskie Studia i Materiały" 2004, nr 7.

Wawrzak-Chodaczek M., Wartości w komunikowaniu, Toruń 2009.

Woś J., Zachowania konsumenckie - teoria i praktyka, Poznań 2009.

www.forbes.pl/artykuły/selekcja/baza-wiedza-csr/definicje-i-standardy-csr,3879,1,12052017.

Żemigła M., Społeczna odpowiedzialność przedsiębiorstwa. Budowanie zdrowej, efektywnej organizacji, Kraków 2007. 


\section{Innovation in creating consumer values as an important factor in socio-economic selection making}

\section{Summary}

Consumption concerns many aspects of human life in both material and non-material dimensions. It shapes the attitude towards the family, spare time management, religion or culture. It sets the shape of our dreams, desires and life aspirations. On the one hand, it affects the system of our values, on the other hand, it is inspired by this system.

Opponents of consumption, treating it as a secondary value and value in itself, accuse it of leading to the development of such phenomena as: mass entertainment, commercialization of culture or development of quite unnecessary, apparent needs. Instead, it removes the values generally respected in society, such as: interest in the fate of others, solidarity, care for the environment or the future of next generations. Today's consumer is not a mindless human being subject to the rules of the market, they are increasingly educated, aware and responsible. They make choices based not only on their own needs but based on values existing in a given society. They purchase wisely and respectfully, remembering that today's choices will be the legacy for future generations, thus the consumer's interest must be synchronized with these generations. Nowadays, it is the consumer who creates the image of the company, forcing it to take ethical and moral actions, and also heading for conscious consumption. Such an attitude creates the opportunity to include the consumer in the processes of companies' activities and their innovations, as well as treating them personally and more like a partner.

In the realities of the new economic, political, and social system, new values of individuals, as well as of entire social groups associated with the behaviour of consumers of the modern world are developing. Consumption, on the one hand, determines the shape of dreams, desires and the way of life. On the other hand, based on an innovative approach to it, it performs a symbolic function that gives a deeper and wider perspective to existing products, emphasizing them as exceeding their useful functions. Consumers becoming more aware of their choices take into account not only the system of their own values but also the values existing in a given society. This innovative approach to consumption creates new quality, a new lifestyle, it shapes new roles, it draws attention to the environment around us, and it cares about the sensible use of its resources and its means.

Following values in the selection of products reveals responsibility connected to decision making, its impact on the environment and on entire social groups. They allow the individual to realize themselves in the group and the human community, they enable human development, achieving customer satisfaction, and avoiding the plundering economy. 